\title{
Influence of water on the circulation of the West Nile Virus in horses in Southern France
}

Sophie Pradier ${ }^{1,2^{*}}$, Alain Sandoz ${ }^{3}$, Gaëtan Lefebvre ${ }^{3}$, Annelise Tran ${ }^{4}$, Sylvie Lecollinet ${ }^{5}$, Agnès Leblond 2,6

From $16^{\text {th }}$ International Symposium on HIV and Emerging Infectious Diseases

Marseille, France. 24-26 March 2010

\section{Background}

West Nile Virus (WNV) affects humans and horses, potentially causing severe neurological manifestations. Recent outbreaks of West Nile fever in horses were reported in Camargue (2000, 2004), Var (2003) and Pyrénées Orientales (2006). The circulation of this virus is strongly influenced by environmental conditions. This study aimed at explaining the circulation of WNV in horses by quantifying water bodies around equine stables using Landsat images.

\section{Methods}

A total of 135 stables were selected in three French departments (Hérault, Gard, Bouches-du-Rhône) and 1161 horses were tested by serological analysis between 2007 and 2008.

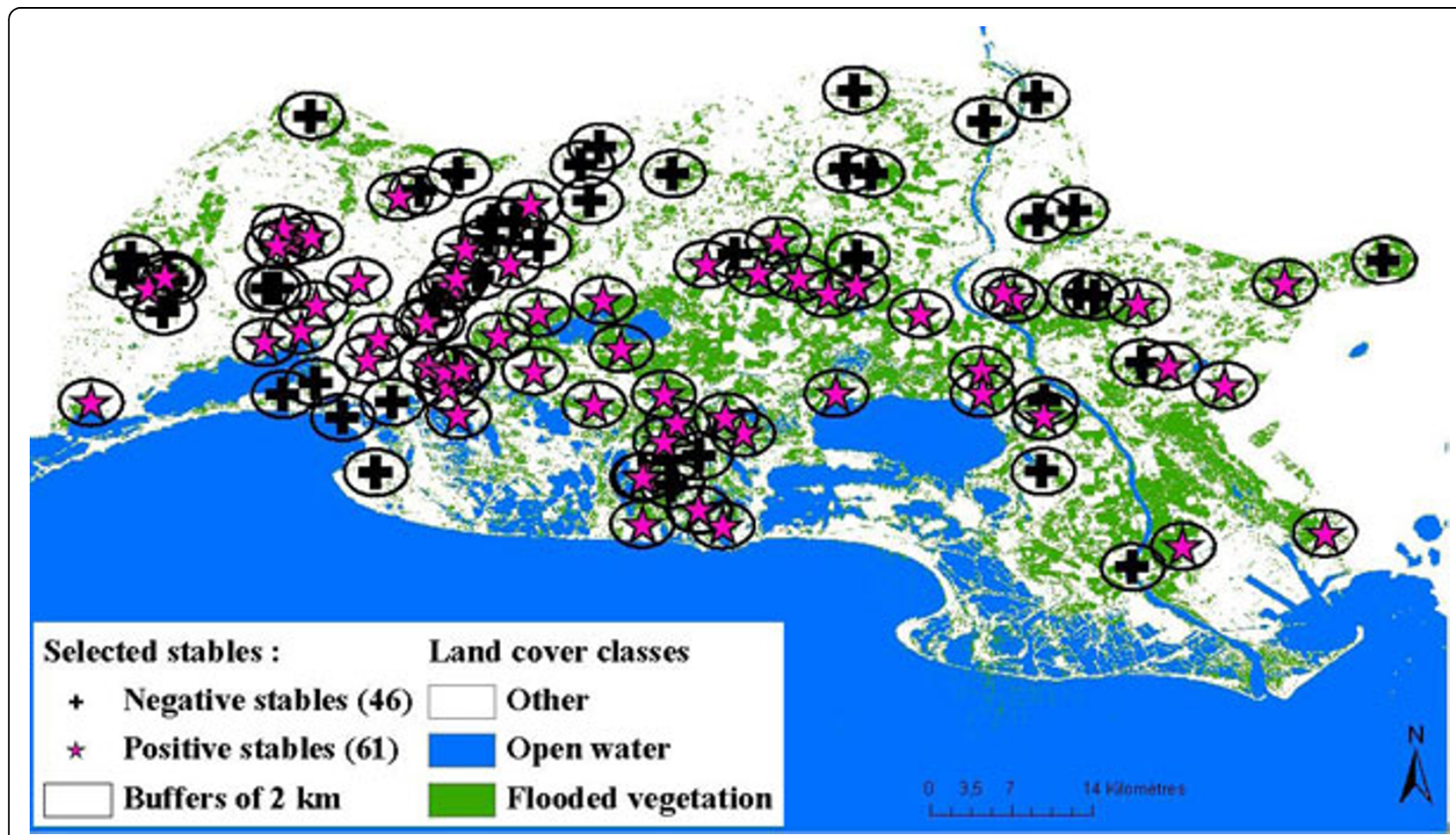

Figure 1 Localisation of stables in the study zone (classification of a Landsat image of September $8^{\text {th }}$ 2007)

\footnotetext{
* Correspondence: spradier@vet-alfort.fr

${ }^{1}$ Clinique équine ENVA, Maisons-Alfort, France 
15 Landsat images (August 2006 to August 2008) were classified into 3 classes: open water, flooded vegetation and other. Surface areas of the first two classes were calculated for buffers of 2 to $5 \mathrm{~km}$ around each stable and for each date.

Two multivariate analyses were conducted: GLMs to identify which environmental variables were involved in the viral circulation in stables and GRMs to identify the horse variables linked to WNV circulation after retrieving the effect of the environment.

\section{Results}

The best model distinguishing 46 negative stables (no positive horse considering an error threshold of 0.15 ) from 61 positive stables (at least 1 positive horse) used $2 \mathrm{~km}$ buffers and included mean area of flooded vegetation, total number of horses present in the stable, mean area of open water and $\mathrm{X}$ and $\mathrm{Y}$ geographic coordinate. The first two variables had a positive effect and the other three a negative effect. The model predicted correctly $73 \%$ of positive stables and $71 \%$ of negative ones. At the horse level, breed, activity and age were significant. See Figure 1.

\section{Discussion}

These results can be used to target the surveillance of this human and equine disease in Southern France.

\section{Author details}

${ }^{1}$ Clinique équine ENVA, Maisons-Alfort, France. ${ }^{2}$ UR 346 Epidémiologie animale INRA, Saint Genès Champanelle, France. ${ }^{3}$ Tour du Valat, Arles, France. ${ }^{4}$ CIRAD Agirs, Montpellier, France. ${ }^{5}$ UMR 1161 Virologie INRA AFSSA ENVA, Maisons-Alfort, France. ${ }^{6}$ Clinéquine ENVL, Marcy l'étoile, France.

Published: 11 May 2010
Submit your next manuscript to BioMed Central and take full advantage of:

- Convenient online submission

- Thorough peer review

- No space constraints or color figure charges

- Immediate publication on acceptance

- Inclusion in PubMed, CAS, Scopus and Google Scholar

- Research which is freely available for redistribution

Submit your manuscript at www.biomedcentral com/submit 